\title{
QUANTIFICATION OF METAL LOSS DUE TO SILT EROSION UNDER
}

\section{LABORATORY CONDITIONS}

\author{
PRAGYAN SENAPATI ${ }^{1}$, RAKESHASHARMA K R ${ }^{2}$, M. K. PADHY ${ }^{3} \&$ U.K.MOHANTY ${ }^{4}$ \\ ${ }^{1}$ Assistant Professor, ITER, SOA University, Bhubaneswar, India \\ ${ }^{2}$ M.Tech Research Scholar, ITER, SOA University, Bhubaneswar, India \\ ${ }^{3}$ Associate Professor, ITER, SOA University, Bhubaneswar, India \\ ${ }^{4}$ Professor, ITER, SOA University, Bhubaneswar, India
}

\begin{abstract}
Mild steel test specimen set at angles of $5^{\circ}, 45^{\circ}$ and $90^{\circ}$ in the slurry flow direction were exposed to silt attack in a pot test rig in the laboratory. The total period of exposure of the specimen to the silt attack was maintained for four

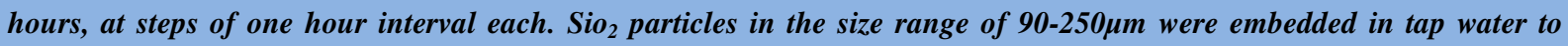
constitute the slurry. The slurry concentration was maintained at 7500 ppm. The shaft carrying the test specimen was rotated at 4032rpm in the slurry to maintain an equivalent water head of 89.85 metres. The surface hardness of the specimen increased progressively with the increase in the time of exposure. Maximum

Average metal loss was recorded for the sample inclined at $45^{\circ}$ in the direction of silt flow while it was minimum for the $90^{\circ}$ samples. The experimental results were in good agreement with the theoretical calculated value for metal loss obtained using finnie's model.

KEYWORDS: Silt Attack, Silt Concentration, Metal Loss, Head of Water \& Finnie's Model
\end{abstract}

Received: Jul 24, 2017; Accepted: Aug 12, 2017; Published: Aug 28, 2017; Paper Id: IJMPERDOCT20175

\section{INTRODUCTION}

Silt erosion refers to the impingement of silt embedded in a fluid medium such as water; air, etc. on surfaces that come across the path of flow of the medium. The silt mostly contains fine $\mathrm{SiO} 2$ particles with a hardness of ' 7 ' in the MohsScale [1-3]. Thus, the impingement of the hard silt particles on the attacked surface damages the surface from abrasion and/or deformation, over a period of time. This phenomenon of silt erosion is of specific interest concerning various machineries involved with the marine, mining, manufacturing and hydropower-generating units that opt for handling aggressive materials such as silt embedded in the run-of-river, for their operation. For instance, hydro turbines, which require a high-water head for their operation, have the different components like the nozzle, needle and buckets exposed to severe erosive actions of the silt contained in the river water that strikes the different parts with great force. These striking hard silt particles damage the different constituent components of the turbine through cutting, fatigue, brittle fracture and plastic deformation. The material separation of the constituent components such as a bucket of the turbine over a period of time may even change the geometry of the component influencing the path and pattern of strike water. Such changes in the path and pattern of strike of the water stream bring in serious alterations in the quantum of transfer of kinetic energy from the water stream to the bucket affecting the performance of the machine adversely and lowering its efficiency. Thus, study of silt erosion and associated quantification of metal loss to predict the life span of 
different components of the machine for its safe

Silt erosion of the machine component is caused principally due to the passage of the water stream containing hard silt particles through the machines initiating a dynamic action of the silt on the surfaces of the components that it strikes. The massive effect of the striking silt can be understood from the data reported by some experimenters according to which some hydro turbine units have to operate under serious abusive conditions due to exposure to as high as 10,000 tons of silt per day per machine, contained in the run of river, in the rainy season [4]. Due to practical as well as economic reasons, different flushing/settling/sedimentation units allow the passage of silt particles less than $0.2 \mathrm{~mm}$ in the treated river-water-stream while preventing the passage of bigger fractions. Therefore, the hydraulic machines operating, based on the transfer of kinetic energy from the flowing water stream, have to handle silt particles less than $0.2 \mathrm{~mm}$. However, several practical examples settle that even $<0.2 \mathrm{~mm}$ sized silt particles impart noticeable damage and metal loss to the machine component on its impingement, on the concerned surface.

Silt erosion is expressed quantitatively by a parameter known as Erosion Rate, W, which is given as the material loss per unit time on account of silt impinge on the target material as influenced by the various operating conditions, properties of the striking silt and the properties of the target material. Time of exposure and the angle of impingement of the silt particles in the target material constitute two of the most important operating parameters influencing the silt erosion rate. It is reported [5] that the erosion rate is severe at lower impingement angles for ductile materials, the rate being maximum at an

Impingement angle between $10^{\circ}$ to $30^{\circ}$ while the same, assumes lower values for $90^{\circ}$ incidents. Bhusan [6] predicts a comparatively higher erosion rate for brittle material in relation to that for ductile materials while the findings of Chen [7] reflect a reverse opinion. The effect of time of exposure of target material to the silt attack is expressed in terms of the flux-rate, which is defined as the mass of the eroding particles per unit area of the target material per unit time. It is interesting to note that beyond a certain flux rate the erosion rate actually reduces with the increase of the flux rate. Experimenters suggest that, decrease of the erosion rate with the flux rate after a certain initial period could be a result of the particles rebounding from the target surface thereby obstructing the freshly arriving particles reducing the effective flux rate.

Several experimenters have developed empirical relationships, expressing the erosion rate as a function of different operational parameter, properties of the target material and the characteristics of the eroding particles [9-16]. These models provide a tool for quantification of metal loss from the target material under specific conditions

Conducted and the model is proposed. The present work is one such attempt. Instead of proposing a fresh model in terms of their experimental results, the experimenters have compared these with the calculated values obtained using Finnie's Model. This model is chosen since it is developed for ductile materials like the mild steel.

\section{EXPERIMENTAL}

The experimental setup comprised of a mild steel, bottom-end-closed drum with a lid having an opening at the centre for introducing the specimen-carrier-shaft that could rotate through a motor-stepped pulley assembly. The pot tester was riveted on to the ground to minimize the vibration during operation. The shaft of the 3-phase, 1500rpm motor was coupled through a V-belt to the shaft carrying the samples for its rotation. The shaft was supported by a ball bearing at its top end near the stepped pulley and a mild steel sleeve welded to the bottom plate of the drum for holding it in position for 
ensuring its concentric rotation about its vertical axis in the slurry of required concentration made up of silica of appropriate size range and tap-water. The motor was operated through a DOL starter to take care of voltage fluctuations ensuring a trouble-free rotation of the shaft at a constant, pre-decided speed generating and maintaining the equivalence of a pre-fixed water head. Test specimen made up of mild steel strips were so fabricated that when attached to the samplecarrying-shaft through the nut and bolt arrangements and rotated along with the shaft, they were set at angles of $5^{\circ}, 45^{\circ}$ and $90^{0}$ respectively to the vertical axis of the shaft. The rotating slurry in the drum, its rotation being actuated by the rotating shaft was an incident on the specimen surface at the respective angles of $5^{\circ}, 45^{\circ}$ and $90^{\circ}$. This meant, the $\mathrm{SiO} 2$ particles impinged on the sample surface at the preset angles of $5^{\circ}, 45^{\circ}$ and $90^{\circ}$. Two specimens: samples at each of the angles were fixed on the shaft and the average effects of $\mathrm{SiO} 2$ impingement on them pertaining to abrasion, weight loss and change of hardness were recorded and considered for analysis.

A constant flux rate was maintained throughout the experiment keeping the slurry concentration at 7500ppm. The rotational speed of the sample carrying shaft was kept at 4032 RPM which ensured the establishment of a constant water head of $89.85 \mathrm{~m}$. The size of the $\mathrm{SiO} 2$ particles in the slurry was maintained in the range of $90-250 \mu \mathrm{m}$ and the time of impingement variance for a total period of 4 hours, with steps of 1 hour each.

After every hour of operation, the machine was switched off. The shaft was dismantled. The specimens were unbolted, wiped clean and dried and their respective weights were recorded. The surface hardness of the test specimens was measured. The photograph of the specimens after every hour of experimentation revealed the surface condition changes due to silt attack. The specimens were re-set on the shaft and the experiment was conducted in a similar way for the $2^{\text {nd }}$ hour. This was continued in the $3^{\text {rd }}$ and the $4^{\text {th }}$ hours respectively, and the weight losses, changes in the surface conditions and surface hardness and cumulative weight loss were recorded.

For the sake of easy reading and understanding the experimental parameters are presented in appendix A. The detailed calculations concerning maintenance of the specific head of water from the speed of rotation of the shaft are placed in appendix B. The photograph of the samples before and after the slurry attack, the shaft carrying the test samples and the experimental arrangements present in appendix C. Calculated mass loss values using Finnie's model, and the concerned detailed calculation are presented in Appendix D.

\section{RESULTS}

The hourly weight loss of the samples is presented in Table No. 1 through Table No. 4. The cumulative weight losses for the samples inclined at different angles to the slurry flow direction are tabulated in Table No.5 through Table No.7. Table No.8 houses the change of hardness values of the target surface as a consequence of silt attack. The average weight loss data is also graphically presented in Figure 5 through Figure 7. The comparison between the average weight loss and calculated weight loss values obtained, using Finnie's model are presented in table no. 11 and shown in fig. 8 .

Table 1: Weight Loss of the Specimen after $1^{\text {st }}$ hour

Run in the Slurry of Concentration 7500ppm

\begin{tabular}{|c|c|c|c|c|c|}
\hline $\begin{array}{l}\text { SPECIMEN } \\
\text { NO. }\end{array}$ & $\begin{array}{l}\text { IMPINGEMENT } \\
\text { ANGLE }\end{array}$ & $\begin{array}{l}\text { WEIGHT } \\
\text { BEFORE } 1^{\text {sT }} \\
\text { RUN (gm) }\end{array}$ & $\begin{array}{l}\text { WEIGHT } \\
\text { AFTER } 1^{\text {sT }} \\
\text { RUN }(\mathrm{gm})\end{array}$ & $\begin{array}{l}\text { WEIGHT } \\
\text { LOSS (gms) }\end{array}$ & $\begin{array}{l}\text { AVERAGE } \\
\text { WEIGHT } \\
\text { LOSS(gms) }\end{array}$ \\
\hline 1 & 5 & 36.0827 & 35.8652 & 0.2175 & \multirow[t]{2}{*}{0.2068} \\
\hline 2 & 5 & 42.6039 & 42.4077 & 0.1962 & \\
\hline 3 & 45 & 39.5675 & 39.4577 & 0.1098 & \multirow[t]{2}{*}{0.1456} \\
\hline 4 & 45 & 39.8444 & 39.6629 & 0.1814 & \\
\hline 5 & 90 & 38.6525 & 38.6209 & 0.0316 & \multirow[t]{2}{*}{0.0419} \\
\hline 6 & 90 & 39.7346 & 39.6823 & 0.0523 & \\
\hline
\end{tabular}


Table 2: Weight Loss of the Specimen after $2^{\text {nd }}$ Hour

Run in the Slurry of Concentration 7500ppm

\begin{tabular}{|c|c|c|c|c|c|}
\hline $\begin{array}{l}\text { SPECIMEN } \\
\text { NO. }\end{array}$ & $\begin{array}{c}\text { IMPINGEMENT } \\
\text { ANGLE }\end{array}$ & $\begin{array}{l}\text { WEIGHT } \\
\text { BEFORE 2 } \\
\text { RUN } \\
\text { RUN) }\end{array}$ & $\begin{array}{l}\text { WEIGHT } \\
\text { AFTER 2 } 2^{\text {NO }} \\
\text { RUN }(\mathrm{gm})\end{array}$ & $\begin{array}{l}\text { WEIGHT } \\
\text { LOSS (gms) }\end{array}$ & $\begin{array}{c}\text { AVERAGE } \\
\text { WEIGHT } \\
\text { LOSS }(\mathrm{gms})\end{array}$ \\
\hline 1 & 5 & 35.8652 & 35.7739 & 0.0913 & \multirow[t]{2}{*}{0.0966} \\
\hline 2 & 5 & 42.4077 & 42.3057 & 0.1019 & \\
\hline 3 & 45 & 39.4577 & 39.3427 & 0.1149 & \multirow[t]{2}{*}{0.0900} \\
\hline 4 & 45 & 39.6629 & 39.5822 & 0.0807 & \\
\hline 5 & 90 & 38.6209 & 38.5725 & 0.0484 & \multirow[t]{2}{*}{0.0467} \\
\hline 6 & 90 & 39.6823 & 39.6372 & 0.0450 & \\
\hline
\end{tabular}

Table 3: Weight Loss of the Specimen after $3^{\text {rd }}$ Hour Run in the Slurry of Concentration 7500ppm

\begin{tabular}{|c|c|c|c|c|c|}
\hline $\begin{array}{c}\text { SPECIMEN } \\
\text { NO. }\end{array}$ & $\begin{array}{l}\text { IMPINGEMENT } \\
\text { ANGLE }\end{array}$ & $\begin{array}{l}\text { WEIGHT } \\
\text { BEFORE } 3^{\text {Ro }} \\
\text { RUN (gm) }\end{array}$ & $\begin{array}{l}\text { WEIGHT } \\
\text { AFTER } 3^{\text {RD }} \\
\text { RUN }(\mathrm{gm})\end{array}$ & $\begin{array}{l}\text { WEIGHT } \\
\text { LOSS (gms) }\end{array}$ & $\begin{array}{c}\text { AVERAGE } \\
\text { WEIGHT } \\
\text { LOSS(gms) }\end{array}$ \\
\hline 1 & 5 & 35.7739 & 35.7567 & 0.0172 & \multirow[t]{2}{*}{0.0203} \\
\hline 2 & 5 & 42.3057 & 42.2824 & 0.0234 & \\
\hline 3 & 45 & 39.3427 & 39.2154 & 0.1273 & \multirow[t]{2}{*}{0.1200} \\
\hline 4 & 45 & 39.5823 & 39.4796 & 0.1026 & \\
\hline 5 & 90 & 38.5725 & 38.5472 & 0.0253 & \multirow[t]{2}{*}{0.0246} \\
\hline 6 & 90 & 39.6372 & 39.6104 & 0.0268 & \\
\hline
\end{tabular}

Table 4: Weight Loss of the Specimen after $4^{\text {th }}$ Hour Run in the Slurry of Concentration 7500ppm

\begin{tabular}{|c|c|c|c|c|c|}
\hline $\begin{array}{l}\text { SPECIMEN } \\
\text { NO. }\end{array}$ & $\begin{array}{c}\text { IMPINGEMENT } \\
\text { ANGLE }\end{array}$ & $\begin{array}{l}\text { WEIGHT } \\
\text { BEFORE } 4^{\text {TH }} \\
\text { RUN (gm) }\end{array}$ & $\begin{array}{l}\text { WEIGHT } \\
\text { AFTER } 4^{\text {TH }} \\
\text { RUN }(\mathrm{gm})\end{array}$ & $\begin{array}{l}\text { WEIGHT } \\
\text { LOSS (gms) }\end{array}$ & $\begin{array}{c}\text { AVERAGE } \\
\text { WEIGHT } \\
\text { LOSS(gms) }\end{array}$ \\
\hline 1 & 5 & 35.7567 & 35.7453 & 0.0126 & \multirow{2}{*}{0.0126} \\
\hline 2 & 5 & 42.2824 & 42.2685 & 0.0139 & \\
\hline 3 & 45 & 39.2154 & 39.1133 & 0.1021 & \multirow[t]{2}{*}{0.1000} \\
\hline 4 & 45 & 39.4796 & 39.3797 & 0.0998 & \\
\hline 5 & 90 & 38.5472 & 38.5282 & 0.0189 & 0.0242 \\
\hline
\end{tabular}

Table 5: At $5^{0}$ Impingement Angle the Cumulative Weight Loss

\begin{tabular}{|c|c|c|}
\hline $7 \mathrm{Mt}$ (bos) & Vitgilou fri & 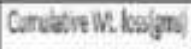 \\
\hline 1 & 0268 & 0.068 \\
\hline 2 & allst & Q3435. \\
\hline 3 & 0028 & 0323 \\
\hline 4 & AQLB & 0.3364 \\
\hline
\end{tabular}




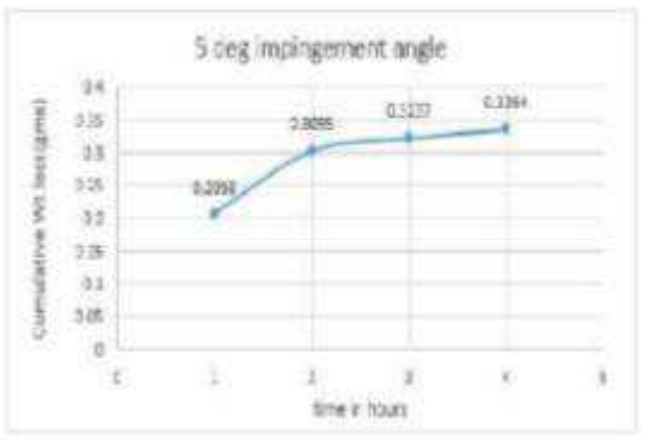

Figure 1

Table 6: At $4^{\circ}$ Impingement Angle the Cumulative Weight Loss

\begin{tabular}{|c|c|c|}
\hline Tes (fous') & Wagt losigs & Qmulat W. lasing) \\
\hline 1 & 0156 & Q156 \\
\hline ? & 0.090 & coses \\
\hline 3 & $\$ 1200$ & 03556 \\
\hline 4 & $\triangle 1000$ & $\cos 4$ \\
\hline
\end{tabular}

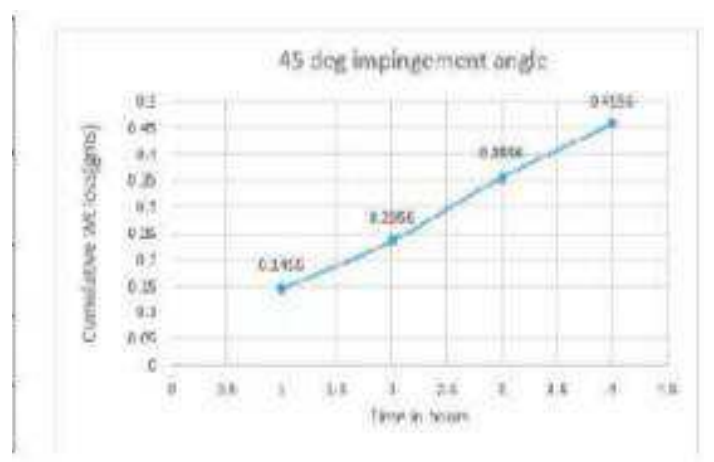

Figure 2

Table 7: At $90^{\circ}$ Impingement Angle the Cumulative Weight Loss

\begin{tabular}{|c|c|c|}
\hline The hous! & 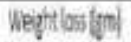 & 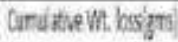 \\
\hline 1 & 0219 & DOA19 \\
\hline ? & Qนะก & 00087 \\
\hline 3 & 20.261 & 01156 \\
\hline 1 & ande & 21338 \\
\hline
\end{tabular}




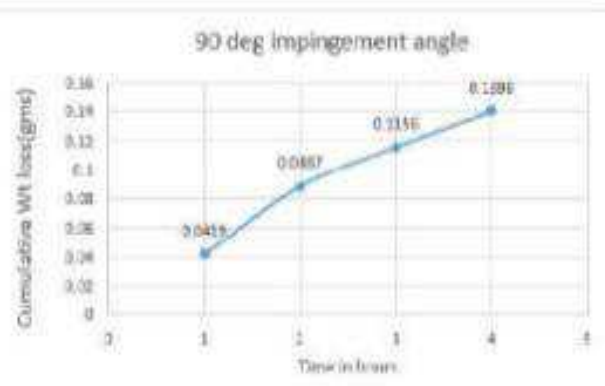

Figure 3

Table 8: Avg. Hardness Values

\begin{tabular}{|c|c|}
\hline $\begin{array}{c}\text { Hours of } \\
\text { Exposure }\end{array}$ & $\begin{array}{c}\text { Hardness of } \\
\text { Specimens } \\
\text { (HRB) }\end{array}$ \\
\hline Initially & 87 \\
\hline 1 & 87.6 \\
\hline 2 & 89.33 \\
\hline 3 & 90 \\
\hline 4 & 90.2 \\
\hline
\end{tabular}

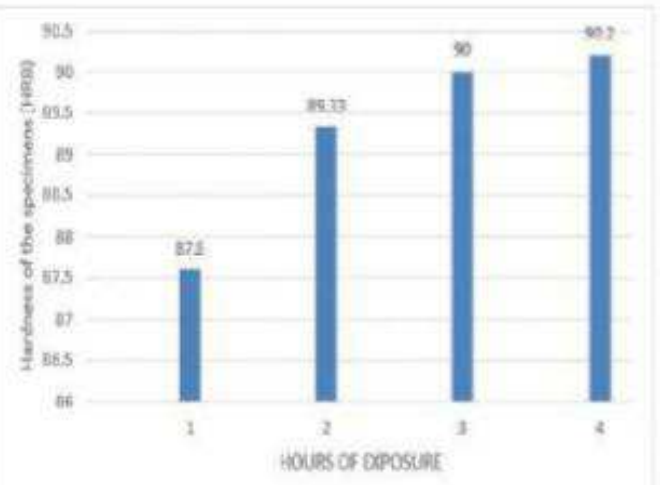

Figure 4

Table 9: Avg. Weight Loss at $5^{0}$ Impingement Angle

\begin{tabular}{|c|c|}
\hline TIME in (hours) & $\begin{array}{c}\text { Avg. Weight loss } \\
\text { (gm) }\end{array}$ \\
\hline 1 & 0.2068 \\
\hline 2 & 0.0966 \\
\hline 3 & 0.0203 \\
\hline 4 & 0.0126 \\
\hline
\end{tabular}




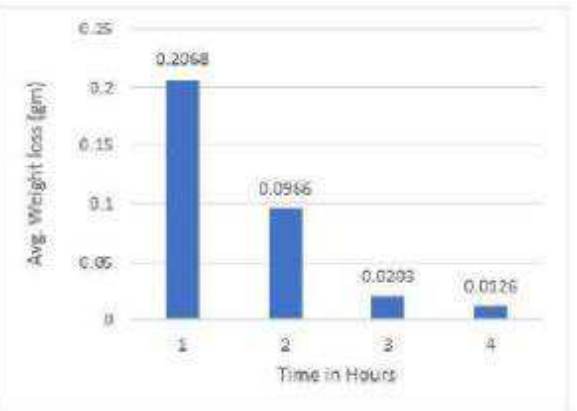

Figure 5

Table 10: Avg. Weight Loss at $\mathbf{4 5}^{\circ}$ Impingement Angle

\begin{tabular}{|c|c|}
\hline TiMe in (hours) & $\begin{array}{c}\text { Avg. Weight loss } \\
\text { (gm) }\end{array}$ \\
\hline 1 & 0.1456 \\
\hline 2 & 0.0900 \\
\hline 3 & 0.1200 \\
\hline
\end{tabular}

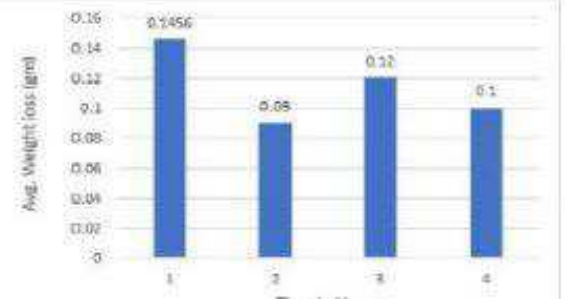

Figure 6

Table 11: Avg. Weight Loss at $90^{\circ}$ impingement Angle

\begin{tabular}{|c|c|}
\hline TIME in (hours) & $\begin{array}{c}\text { Avg. Weight loss } \\
\text { (gm) }\end{array}$ \\
\hline 1 & 0.0419 \\
\hline 2 & 0.0467 \\
\hline 3 & 0.0261 \\
\hline 4 & 0.0242 \\
\hline
\end{tabular}

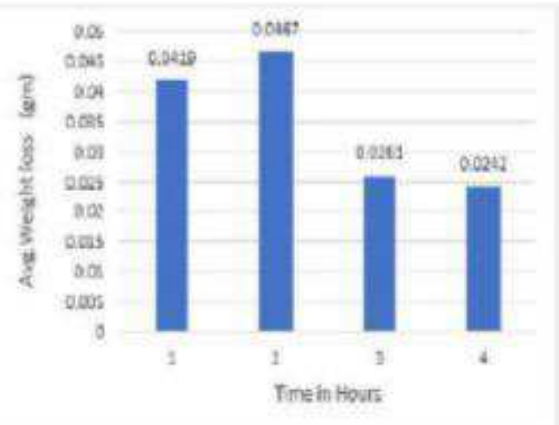

Figure 7 
Table 12: Comparison between Average Weight Loss and Finnie's Model

\begin{tabular}{|l|l|l|}
\hline $\begin{array}{l}\text { IMPINGEMENT } \\
\text { ANGLE }\end{array}$ & $\begin{array}{l}\text { AVG WEIGHT } \\
\text { LOSS (gm) }\end{array}$ & $\begin{array}{l}\text { FINNIE } \\
\text { MODEL }\end{array}$ \\
\hline 5 & 0.0841 & 0.0943 \\
\hline 45 & 0.1139 & 0.1019 \\
\hline 90 & 0.0347 & 0 \\
\hline
\end{tabular}

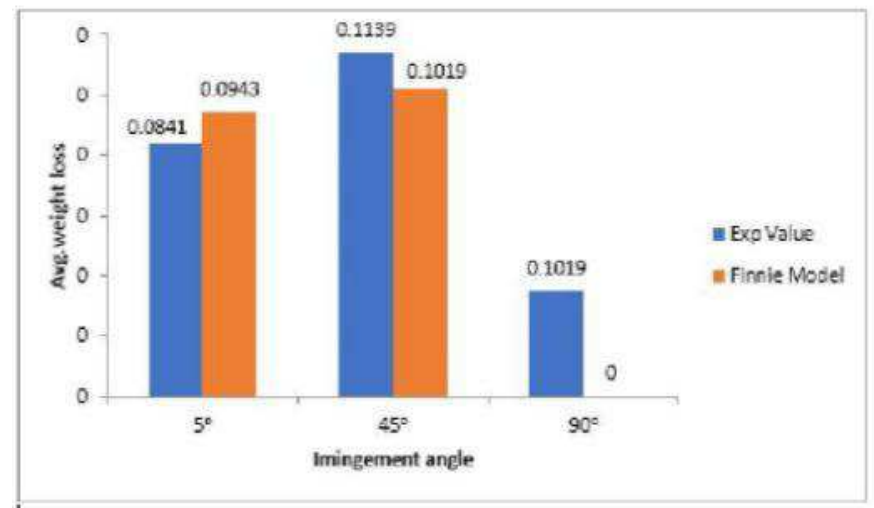

Figure 8

\section{DISCUSSIONS}

It is interesting to note that the cumulative mass loss versus the time of impingement curve shows an upward trend over the entire period of experiment. This establishes the fact that under the bounds of the experimental conditions the weight loss due to silt erosion increases with the time of exposure of the test specimens to the silt attack. However, a closure look at the curves reveals that the enhancement of the erosion rate (rate of metal loss) is not constant over the total period of experimentation. For all the samples, for the $1^{\text {st }}$ hour, the metal loss increases at a higher rate. For the samples inclined at $5^{\circ}$ and $90^{\circ}$ the increase of rate of metal loss subsequently decreases where as for the sample inclined at $45^{\circ}$ to the direction of flow of slurry, the rate of mass loss over the entire period is almost constant. This is attributed to the various mutually competing factors such as the increase of hardness of the substrate material due to particle impingement and the effective flux rate, the related mechanism involved etc.

As evidenced from Table 8 and Figure 4 the surface hardness of the target surface increases with the increase of time of exposure of the test specimen to the silt attack. Obviously, as a consequence of increase in the surface hardness the subsequent rate of metal loss decreases with time. This is in line with the findings of the metal does not change much, erosion rate does not change significantly though with the increase of softness of the metal the erosion rate becomes higher undergoing a significant change. The decrease of the rate of erosion may also be a consequence of gradual rounding up of sharp edged hard silica particles with the lapse of time; since even hard particles with rounded edges cannot causes severe erosion [18] as a thumb rule. Thus, particles with rounded edges exhibit lower erosion rates where as the reverse is true in case of angular particles with sharp edges $[19,20]$. The lowering in the erosion rate may also be a result of the decreased flux-rate, which is expressed in terms of the mass of the eroding particles incident per unit area of the target surface per unit time. After certain initial time lapse, the particles rebounding from the target surface are most likely to interfere with the freshly arriving particles reducing the effective flux-rate, thus lowering the rate of metal loss [21]. 
Ductile materials like the mild steel test specimens in the present case show severe erosion at lower impingement angles, the maximum erosion rate being observed between $10^{\circ}$ to $30^{\circ}$ angles of impingement [21]. Matsumura et.al. [22], on the basis of their experimental results, have shown that erosion rate of ductile materials is higher compared to that of brittle materials, in general. In the present case for low angles of impingement (say $5^{0}$ ) the mechanism involved is a cutting mechanism whereas for high impact angles $\left(\mathrm{say} 90^{\circ}\right)$ the same adopts a fatigue erosion mechanism. Resulting in ways built up, being involved in ploughing that is a less efficient mechanism for metal removal. Thus, the subsequent detachment of metal debris is caused due to further repeated hitting of the solid grit and as witnessed from the experimental results, for $90^{\circ}$ incident the metal loss from the target surface assumes lower value. This is clearly evident from the related photographs However, for $45^{\circ}$ impingements, the angle of impingement is neither very high nor very low. The erosion mechanism involved may include both cutting and fatigue erosions in this case. It is well accepted that material removal from the target surface is faster if the mechanism involves both cutting and fatigue [23]. On account of the above, the material being ductile mild steel, erosion rate assumes higher values in the present case for the sample inclined at $45^{\circ}$ to the flow direction of the slurry. Thus, despite of the factors decreasing the erosion rate for this sample adopts an increasing trend throughout the entire period of its exposure to the silt attack as presented in table 1-11 and figure 1-8

\section{Comparison of Experimental metal loss and calculated avg. metal loss}

The Finnie's model, on the basis of calculation in Appendix D is presented in figure 8. From the figure following can be concluded. Thus, it can be observed

For lower angles of impingement, the results agreed the most, the difference between the two being a mere $1.02 \%$.

For $45^{0}$ impingements, the model yielded a lower result than the experimental results, the difference being $1.2 \%$.

For $90^{\circ}$ impingements, the model yielded zero results where as the experimental showed an erosion loss of 0.0347 gms, $0.088 \%$ weight of the original sample.

\section{CONCLUSIONS}

The experiment conducted in the laboratory demonstrates the effect of the angle of impingement and time of exposure of a ductile metal surface to the hard-moving silt particles in water. The results pertaining to metal loss have been authenticated by comparing the same with the calculated metal loss values as obtained through Finnie's model. Analysis of the test result shows that the metal loss is affected by different associated competing factors such as surface hardness of the test specimen flux rate, rounding of the sharp edges of the striking grit and mechanism of erosion, responsible for reduction /enhancement of the erosion rate. It is also being shown that ductile metal surface gets work hardened due to a sort /pinning effect on account of the hard silica particles hitting against it and that the surface hardening tends to reduce the erosion rate

\section{REFERENCES}

1. Tong D. Cavitation and wear on hydraulic machines. International Water Power and Dam Construction 1981;(April).

2. $\quad$ Pande VK Conference of CBIP. Criteria for developing silt erosion model test facility 1987.

3. Singh SC. Operational problems and development of a new runner for silt water. International Water Power and Dam Construction 1990;(November).

4. Naidu BSK. Silting problem in hydro power plant \& their possible solutions. India: NPTI; 2004.

5. Finnie, I. (1972), “Some Observations on the Erosion of Ductile Metals”, Wear (19), 81-90. 
6. Bhushan, B. (2002), Introduction to Tribology, $1^{\text {St }}$ edition. John Wiley \& Sons, New York.

7. Chen, Q. and Li, D. Y. (2003), “Computer Simulation of Solid Particle Erosion”, Wear (254), 203-210.

8. Arnold J.C and Hutchings I.M. (in 1989) Flux rate

9. Padhy, M.K. and Saini, R.P., 'Effect of size and concentration of silt particles on erosion of Pelton turbine bucket, (2011), Energy 34 (2009) 1477-1483, Elsevier publication.

10. Bardal E. (1985) Korrosjonogkorrosjonsvern, Tapir, Trondheim (In Norwegian)

11. Finnie I. (1960) Erosion of surfaces by solid particle, Wear (3) pp 87-103

12. Bitter J. G. A. (1963) A Study of Erosion Phenomena, Part I and II, Wear (6) pp 5 - 21 and $169-190$

13. Neilson, J. and Gilchrist, A. (1968), “Erosion by a Stream of Solid Particles”, Wear (11), 111-122.

14. Hutchings, I.M., and Winter, R.E. (1974), "Particle Erosion of Ductile Metals: a Mechanism of Material Removal", Wear (27), 121-128.

15. Manson, S.S. (1996), 'Thermal Stress and Low Cycle Fatigue'- McGrawHill,New York,pp-246-254.

16. Hashish, M. (1987), "Modified model for erosion”, Seventh International Conference on Erosion by Liquid and Solid Impact, Cambridge, England, 461-480.

17. Shida Y. and Fujikawa H. (1985) Particle erosion behavior of boiler tube material in elevated temperature, Wear (103) pp 121-139

18. SHELDON G. L. and FINNIE I. (1966) On the ductile behavior of nominally brittle material during erosion cutting, Transaction of ASME (88B) pp 387-392

19. Drolon H. and Druaux F. and Faure A. (2000) Particle shape analysis and classification using wavelet transforms, Pattern recognition letters (21) pp 473-482

20. Stachowiak G. W. (2002) Particle angularity and its relationship to abrasive and erosive wear, Wear (241) pp 214-219

21. Basnyat S. (1999) Monitoring sediment load and its abrasive effects in Jhimruk hydropower plant Nepal, Proc. Optimum use of run-off-river conf., Trondheim

22. Bardal E. (1985) Korrosjonogkorrosjonsvern, Tapir, Trondheim (In Norwegian)

23. Matsumura M. and Chen B.E. (2002) Erosion-resistant materials, In: Duan C.G. and Karelin V.Y. (eds),Abrasive erosion and corrosion of hydraulic machinery,pp 235-314, Imperial college press, London

24. Lim, S.C. and Brunton, J.H., (1985), 'A Dynamic Wear Test Rig for the Scanning Electron Microscope', Wear (101), pp29-50.

\section{APPENDIX A}

\section{Operating Parameters}

The factors are silt concentration, shape, size, velocity and head was kept constant. The two variants were

- Operating hours: 4 hours (with 1 hour interval)

- Impingement angle: $5^{0}, 45^{\circ}, 90^{\circ}$.

For each impingement angle two specimens were taken and their average value was recorded 


\section{APPENDIX B}

\section{Head Calculation}

Maximum speed of the motor, Nmax $=4031$ rpm $\mathrm{W}=(2 \pi / 60) \times$ NMAX

$\mathrm{W}=422.154 \mathrm{rad} / \mathrm{sec}$

Now, Where $r=95.25 \mathrm{~mm} \mathrm{~V}=\mathrm{r} \times \mathrm{w}$

$\mathrm{V}=95.25 \times 422.154$

$\mathrm{V}=40210.1685 \mathrm{~mm} / \mathrm{sec}$

Where $\mathrm{v}=$ velocity of the stirrer shaft with the

Specimen we know,

$\mathrm{V}=\mathrm{Cv}(2 \mathrm{gH})^{1 / 2}$

$40210.1685=0.98 \times(2 \times 9800 \times \mathrm{H})^{1 / 2}$

H $=8589.156$ mm or 85.894

\section{SLURRY CONCENTRATION CALCULATION}

Height of the water tank $H=36 \mathrm{~cm}$ Diameter of the water tank $D=60 \mathrm{~cm}$

Circumference of the tank $\mathrm{C}=2 \pi \mathrm{r}=188.495 \mathrm{~cm}$ Therefore, volume of the tank $\mathrm{V}=\pi / 4 \times \mathrm{D}^{2} \times \mathbf{H}$

$\mathbf{V}=\mathbf{1 0 1 7 8 7 . 6}$ ccVolume $\mathrm{V}=0.101787 \mathrm{~m}^{3}$ or $\mathrm{V}=101.787602 \mathrm{Lt}$

As the desired concentration is $7500 \mathrm{ppm}$, the sand required is, $7500 \mathrm{ppm}$ in $101.787602 \mathrm{Lt}=7.5 \times 101.7876$ $\mathbf{= 0 . 7 6 3 4} \mathbf{k g}$ of silt per $101.787602 \mathrm{Lt}$ of water is required.

\section{APPENDIX C}

Experimental setup for Pot Test Rig

- DOL STARTER: (direct on line)

- THREE PHASE ELECTRICAL MOTOR

- WATER TANK

- $\quad$ ROTATING SHAFT

- $\quad$ PULLEY AND BELT ARRANGEMENT

- FIXTURE SHAFT 


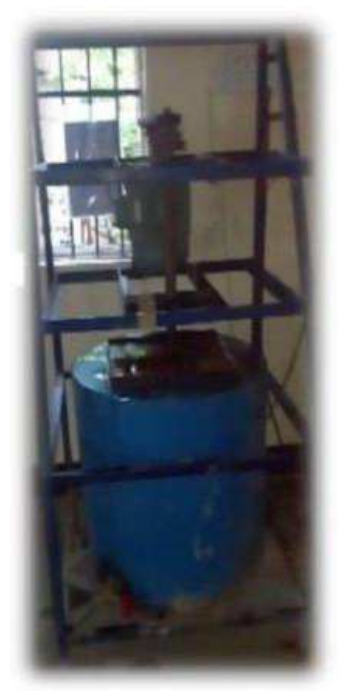

Figure 9

\section{DOL STARTER AND THREE PHASE ELECTRICAL MOTOR}
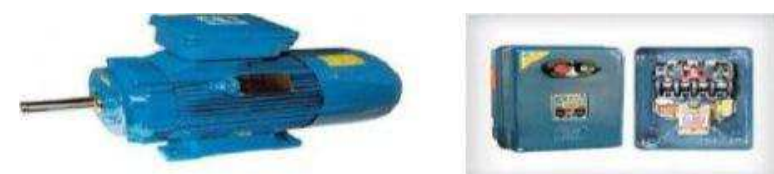

Figure 10

Direct online starter is preventing the motor from the damage caused due to heavy current flow.

A 3 Phase motor of 1500rpm was used for rotating the whirling arm along with a DOL starter.

$$
\begin{array}{ll}
Q=\frac{M V^{2}}{24 P} \times\left(\cos \alpha^{2}\right) & \text { if } \propto \geq 18.5^{\circ} \\
Q=\frac{0.75 \times 40.23^{2}}{24 \times 248} \times\left(\cos 45^{2}\right) &
\end{array}
$$

\section{ROTATING SHAFT AND FIXTURE SHAFT WITH SPECIMENS}

$Q=0.1019 \mathrm{gms}$
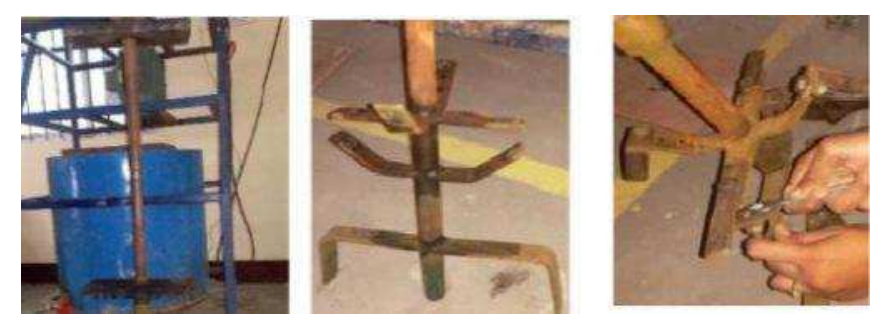

Figure 11

Slurry whirling arm to which specimen are fixed and the arm is connected to the pulley for power transmission.

\section{WATER TANK AND STEPPED CONE PULLEY:}



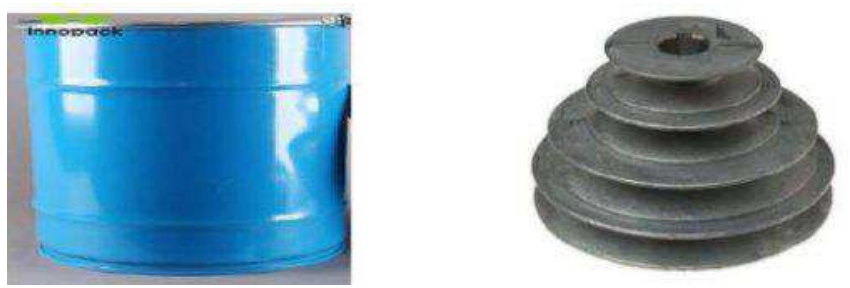

Figure 12

Water tank or drum of $52.07 \mathrm{~cm}$ height and $19 \mathrm{~cm}$ radius.

Pulley and Belt setup are attached to the motor and the other to the whirling arm.

THE SPECIMENS BEFORE EXPERIMENTATION:

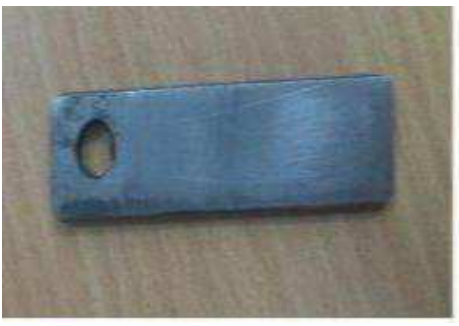

IMPING ANGLE 90

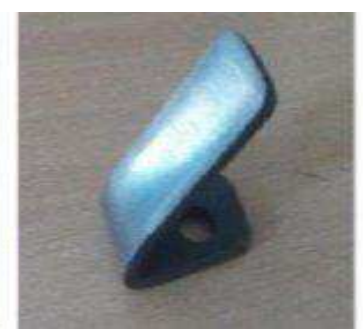

IMPING ANGLE $45^{\circ}$

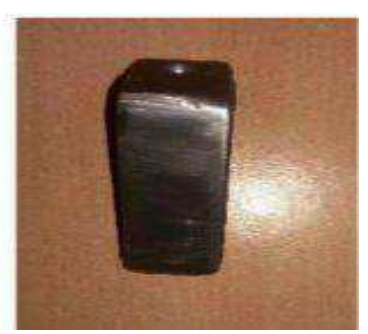

IMPING ANGLE $5^{0}$

Figure 13

\section{THE SPECIMENS AFTER EXPERIMENTATION}

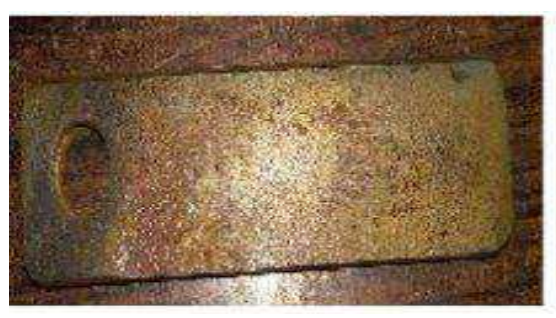

IMPING ANGLE 90

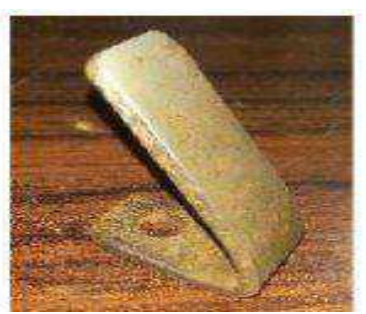

IMPING ANGLE $4^{\circ}$

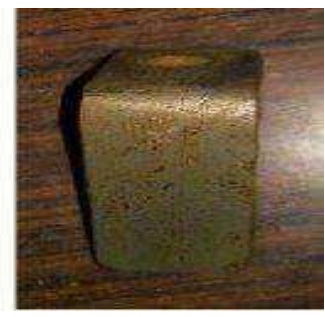

IMPING ANGLE $5^{0}$

Figure 14

\section{APPENDIX D}

Calculation for $7500 \mathrm{ppm} 5^{0}$ impingement angle Using Finnie model

$$
\begin{aligned}
& Q=\frac{M V^{2}}{8 P} \times\left(\sin 2 \alpha-3 \sin ^{2} \alpha\right) \quad \text { if } \propto \leq 18.5 \\
& Q=\frac{0.75 \times 40.23^{2}}{8 \times 248} \times\left(\sin 2(5)-3 \sin ^{2} 5\right) \\
& Q=0.09228 \mathrm{gms}
\end{aligned}
$$

The mass loss from the target surface at $90^{\circ}$ impingement angle, did not exist 
